\title{
Biofabrication of Tissue Scaffolds
}

\author{
Ning Zhu and Xiongbiao Chen \\ Additional information is available at the end of the chapter \\ http://dx.doi.org/10.5772/54125
}

\section{Introduction}

Tissue engineering is an emerging interdisciplinary field that applies the principles of life science and engineering to produce engineered tissues for the repair and replacement of damaged tissues or organs [1]. In tissue engineering, tissue scaffolds play a crucial role. A tissue scaffold is a three-dimensional (3D) structure made from biological materials and biomaterials, which is used to facilitate cell/tissue growth and the transport of nutrients and wastes while degrading gradually itself. To fabricate such tissue scaffolds, a number of fabrication techniques have been developed and reported in the literature and these techniques can generally be classified into two categories: conventional and advanced. Conventional techniques [2], including solvent-casting, particulate-leaching, and freeze drying, can build scaffolds with interconnected porous structures. However, they offer little capacity to precisely control pore size, pore geometry, pore interconnectivity, and spatial distribution of pores or allow for the construction of internal channels within the scaffolds. Ideally, scaffolds should not only provide a supporting structure but also the chemical, mechanical, and biological signals required to respond to environmental stimuli. As an alternative to conventional scaffold fabrication methods, advanced fabrication techniques have recently been developed in tissue engineering, such as electrospinning [3], a nanotechnology-based fabrication technique, and rapid prototyping [4], a class of techniques by which a 3D scaffold is fabricated by laying down multiple, precisely formed layers in succession. With the development of such advanced tissue engineering fabrication techniques, the new concept of "biofabrication" has emerged. Biofabrication is defined as the production of complex living and non-living biological products from raw materials, such as living cells, molecules, extracellular matrices, and biomaterials. It has the potential to be the manufacturing paradigm of the $21^{\text {st }}$ century and makes a significant contribution to the development of tissue engineering strategies [5]. 


\section{Overview of scaffold-fabrication techniques}

\subsection{Conventional fabrication techniques}

Many techniques are available to process synthetic and natural biomaterials into various scaffolds. These include conventional techniques, such as solvent-casting and particulateleaching [6], gas foaming [7], phase separation [8], melt molding [9], and freeze drying [10], among others. An overview of these different techniques follows.

1. Solvent-casting and particulate-leaching (Figure 1a):

Solvent-casting and particulate-leaching techniques involve using a polymer solution uniformly mixed with salt particles of a specific diameter. The solvent then evaporates leaving behind a polymer matrix with salt particles embedded throughout. The composite is immersed in water, where the salt leaches out to produce a porous structure [11]. Highly porous scaffolds with porosity values up to $93 \%$ and average pore diameters up to $500 \mu \mathrm{m}$ can be formed using this technique. A disadvantage of this technique is that it can only be used to produce thin membranes up to $3 \mathrm{~mm}$ thick [12].

2. Gas foaming (Figure 1b):

During the gas foaming process, molded biodegradable polymers are pressurized at high pressures with gas-foaming agents, such as $\mathrm{CO}_{2}$ and nitrogen [13], water [14], or fluoroform [15], until the polymers are saturated. This results in nucleation and growth of gas bubbles with sizes ranging between 100 and $500 \mu \mathrm{m}$ in the polymer. This technique has the advantage of being an organic solvent-free process; the major drawback is that the process may yield a structure with largely unconnected pores and a non-porous external surface [16].

3. Phase separation (Figure 1c):

During the phase separation process, a polymer solution is quenched and undergoes a liquid-liquid phase separation to form two phases; a polymer-rich phase and a polymer-poor phase. The polymer-rich phase solidifies and the polymer poor phase is removed, leaving a highly porous polymer network [17]. The micro- and macro-structure of the resulting scaffolds are controlled by varying process parameters such as polymer concentration, quenching temperature, and quenching rate. The process is conducted at low temperatures, which is beneficial for the incorporation of bioactive molecules in the structure. Using phase separation techniques, nano-scale fibrous structure enables to be formed, which mimics natural extracellular matrix architecture and provides a better environment for cell attachment and function [18].

4. Melt molding (Figure 1d):

Melt molding involves filling a mold with polymer powder and a porogen component and then heating to above the glass-transition temperature of the polymer while applying pressure to the mixture [19]. During the fabrication process, the raw materials will bind together to form a scaffold with designed specified external shape. Once the mold is removed, the 
porogen is leached out and the porous scaffold is then dried. Melt-molding with porogenleaching is a non-solvent fabrication process that allows independent control of morphology and shape. Drawbacks include the possibility of residual porogen and high processing temperatures that preclude the ability to incorporate bioactive molecules.

5. Freeze drying (Figure 1e):

Polymeric porous scaffolds can be prepared by freeze drying. In the freezing stage, the polymer solution is cooled down to a certain temperature at which all materials are in a frozen state and the solvent forms ice crystals, forcing the polymer molecules to aggregate into the interstitial spaces. In the second phase, the solvent is removed by applying a pressure lower than the equilibrium vapor pressure of the frozen solvent. When the solvent is completely sublimated, a dry polymer scaffold with an interconnected porous microstructure remains [20, 21]. The porosity of the scaffolds depends on the concentration of the polymer solution; pore size distribution is affected by the freezing temperatures. Apart from fabricating porous scaffolds, this technique is also used to dry biological samples to protect their bioactivities [22].

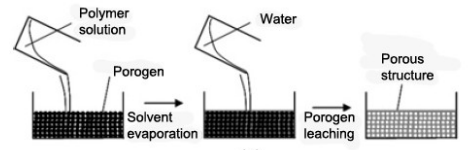

(a)

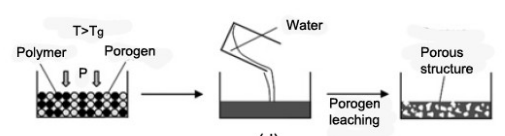

(d)

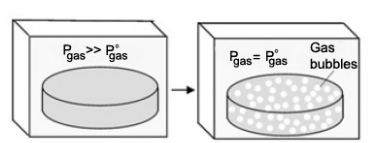

(b)

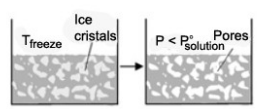

(e)

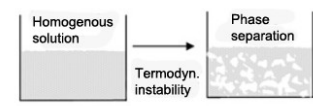

(c)

Figure 1. Schematic of conventional scaffold fabrication techniques: (a) solvent-casting and particulate-leaching process: A polymer solution is cast into a mold filled with porogen particles, then the solvent is allowed to evaporate and the porogen is leached out; (b) gas foaming process: Polymer samples are exposed to high pressure allowing saturation of the gas into the polymer; the subsequent gas pressure reduction causes the nucleation of bubbles; (c) phase separation process: A thermodynamical instability is established in a homogeneous polymer solution that separates into a polymer-rich and a polymer-poor phase; $(d)$ melt molding process. A mold filled with polymer powder and porogen component is heated to above the polymer glass-transition temperature $\left(T_{g}\right)$ and a pressure $(P)$ is applied to the mixture. The porogen is then leached out, leaving a porous structure; (e) freeze drying process: A polymer solution is cooled down, leading to the formation of solvent ice crystals. Then the solvent is removed by using a pressure lower than the equilibrium vapor pressure of the solvent ( $\mathrm{P}^{\circ}$ solution), leaving a porous structure. (Modified from [23])

\subsection{Advanced biofabrication techniques}

1. Electrospinning

Electrospinning is a fabrication technique utilizing electrical charges to draw fine fibers up to the nanometer scale. The technique was invented by Cooley and Morton in 1902. The fiber electrospinning can also be traced back to the 1930s [24]. In the past decade, significant developments in electrospinning have allowed for creation of scaffolds with different materials and, hence, this technique has gained a high popularity in tissue engineering research. 
Nanofibrous architectures are known to modulate effects on a wide variety of cell behaviors. Nanofibrous architectures can positively affect cell binding and spreading compared to micropore and microfibrous architectures (Figure 2). Nanofibrous scaffold architectures have larger surface areas to adsorb proteins than micro-architectures, presenting more binding sites to cell membrane receptors [25]. The exposure of additional cryptic binding sites may also be affected by adsorbed proteins. Furthermore, cells growing in a 3D nanofibrous structural environment are able to exchange nutrients and utilize receptors throughout their surface, while cells in flat culture conditions are limited to nutrient exchange on only one side. Electrospinning techniques have been widely employed to fabricate porous scaffolds with nanofibrous architectures that can mimic the structure and biological functions of the natural extracellular matrix [26]. This technique is able to generate fibers with diameters ranging from $2 \mathrm{~nm}$ to several micrometers using solutions of both natural and synthetic polymers, with small pore sizes and high surface area to volume ratios. A typical electrospinning setup includes three parts: a syringe pump containing the polymeric materials, a high voltage source to generate high electric field for spinning, and a collector to collect the fibers [27] (Figure 3). During scaffold fabrication, the following electrospinning parameters are very important with respect to the fiber morphology: polymer solution parameters (viscosity, molecular weight of polymer, polymer conductivity, surface tension), processing parameters (applied voltage, distance between tip and collector, flow rate), and environment parameters (humidity, temperature). Nanofibers with high surface area to volume ratios are most suitable for tissue engineering applications [28].

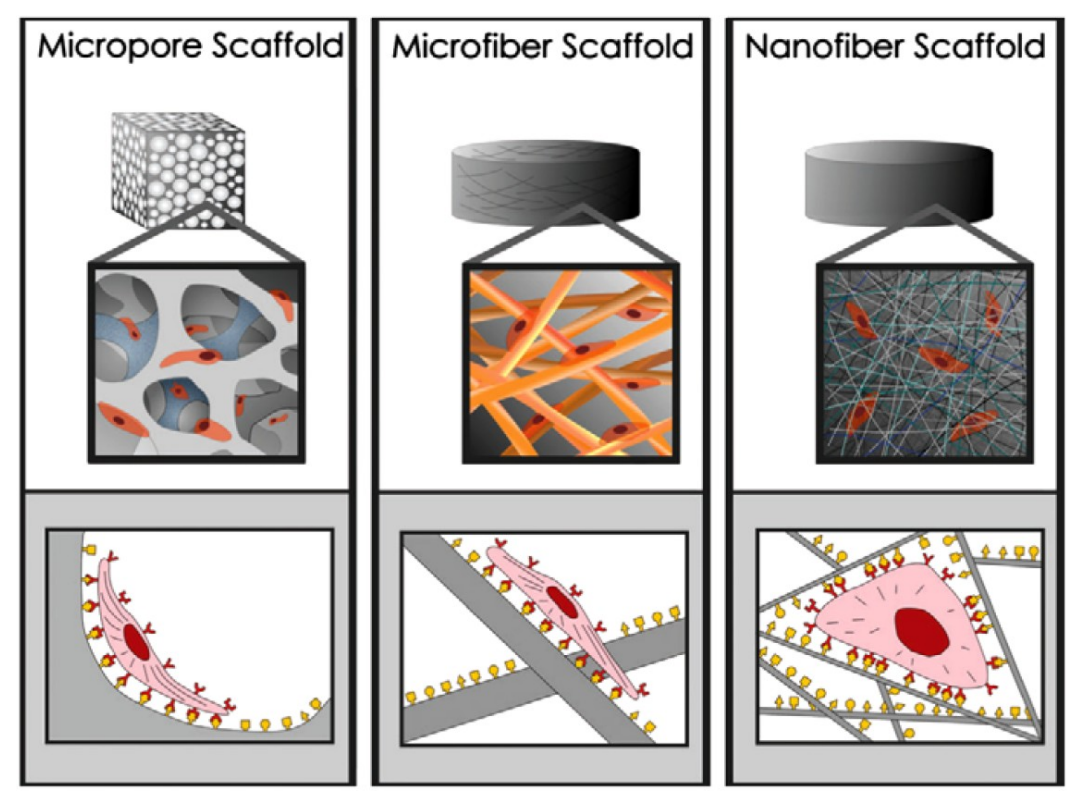

Figure 2. Scaffold architecture affects cell binding and spreading. (Modified from [25]) 


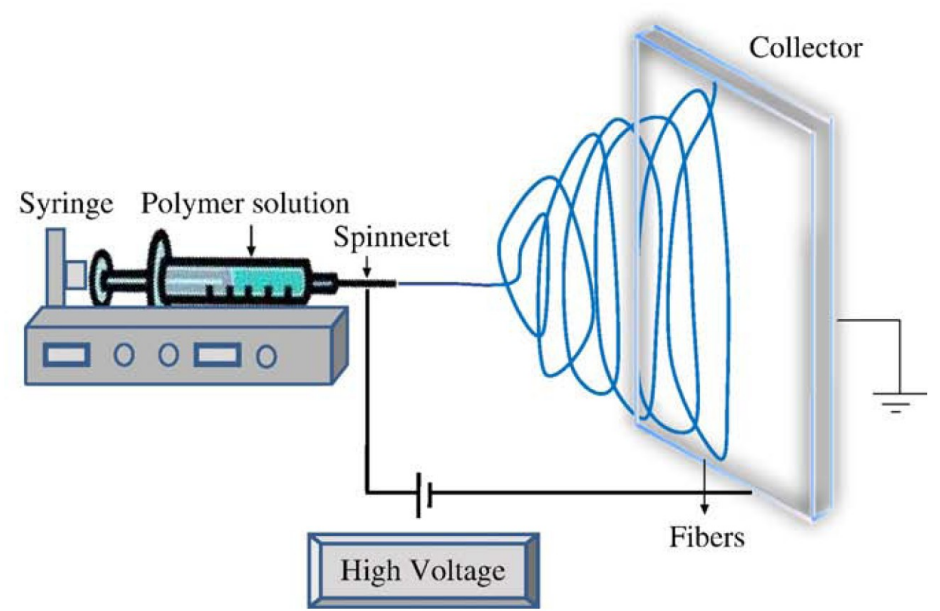

Figure 3. Schematic of electrospinning apparatus. (Modified from [29])

2. Rapid prototyping

As an alternative to conventional scaffold fabrication methods, a group of techniques based on rapid prototyping (RP) has recently been introduced within the tissue engineering field. $\mathrm{RP}$ techniques, based on computer assisted design (CAD) and manufacturing (CAM) techniques, allow for better control of scaffold internal microstructure and external macroshape compared to conventional fabrication techniques [4,30]. Three basic RP system types: liquid-based, solid-based, and powder-based can be selected based on the properties of different scaffold biomaterials. The primary RP processes applied to tissue scaffold fabrication include stereolithography (SLA) [31], selective laser sintering (SLS) [32], fused deposition modeling (FDM) [33], three dimensional (3D) printing [34], and 3D plotting [35]. The choice of materials for the RP techniques includes various polymers, ceramics, and metals. Recently, RP techniques have also demonstrated their capacity for embedding living cells [36, 37] and growth factors [38] into scaffolds during the fabrication process and thus their utility for creating biomimetic tissue scaffolds. 


\begin{tabular}{|c|c|c|c|c|c|}
\hline Technology & Types & Materials & Advantages & Disadvantages & $\begin{array}{l}\text { Tissue } \\
\text { Engineering } \\
\text { Applications }\end{array}$ \\
\hline SLA & Liquid-based & $\begin{array}{l}\text { Polymers, } \\
\text { wax or wax } \\
\text { compounds }\end{array}$ & $\begin{array}{l}\text { Good mechanical } \\
\text { strength; } \\
\text { easy to remove support } \\
\text { materials; } \\
\text { easy to achieve small } \\
\text { features }\end{array}$ & $\begin{array}{l}\text { Limited to reactive } \\
\text { resins (mostly toxic) }\end{array}$ & $\begin{array}{l}\text { Bone [39], } \\
\text { Heart valves } \\
{[40]}\end{array}$ \\
\hline SLS & Powder-based & $\begin{array}{l}\text { Metals, } \\
\text { ceramics, } \\
\text { bulk } \\
\text { polymers }\end{array}$ & $\begin{array}{l}\text { Good mechanical } \\
\text { strength; high accuracy; } \\
\text { broad range of materials }\end{array}$ & $\begin{array}{l}\text { Elevated } \\
\text { temperatures; local } \\
\text { high energy input; } \\
\text { uncontrolled porosity }\end{array}$ & $\begin{array}{l}\text { Bone }[41,42] \text {, } \\
\text { Cartilage [43]. }\end{array}$ \\
\hline FDM & Solid-based & $\begin{array}{l}\text { Some } \\
\text { thermoplastic } \\
\text { polymers/ } \\
\text { ceramics }\end{array}$ & $\begin{array}{l}\text { Low costs; } \\
\text { good mechanical } \\
\text { strength; } \\
\text { versatile in lay-down } \\
\text { pattern design }\end{array}$ & $\begin{array}{l}\text { Elevated } \\
\text { temperatures; } \\
\text { small range of bulk } \\
\text { materials }\end{array}$ & $\begin{array}{l}\text { Bone [44], } \\
\text { Adipose [45], } \\
\text { Cartilage [46]. }\end{array}$ \\
\hline 3D printing & Powder-based & $\begin{array}{l}\text { powder of } \\
\text { bulk } \\
\text { polymers; } \\
\text { ceramics }\end{array}$ & $\begin{array}{l}\text { Fast processing; } \\
\text { low costs; } \\
\text { no toxic components; } \\
\text { water used as binder }\end{array}$ & $\begin{array}{l}\text { Material must be in } \\
\text { powder form; } \\
\text { weak bonding } \\
\text { between powder } \\
\text { particles; } \\
\text { rough surface; } \\
\text { trapped powder issue; } \\
\text { might require post- } \\
\text { processing }\end{array}$ & Bone [47], \\
\hline 3D plotting & $\begin{array}{l}\text { Liquid-based or } \\
\text { solid-based }\end{array}$ & $\begin{array}{l}\text { Swollen } \\
\text { polymers } \\
\text { (hydrogels); } \\
\text { thermoplastic } \\
\text { polymers; } \\
\text { reactive } \\
\text { resins; } \\
\text { ceramics }\end{array}$ & $\begin{array}{l}\text { Broad range of materials } \\
\text { and conditions; } \\
\text { incorporation of cells and } \\
\text { proteins }\end{array}$ & $\begin{array}{l}\text { Slow processing; } \\
\text { no standard } \\
\text { condition; } \\
\text { time consuming } \\
\text { adjustment to new } \\
\text { materials; } \\
\text { low mechanical } \\
\text { strength }\end{array}$ & $\begin{array}{l}\text { Bone [48], } \\
\text { Cartilage [49]. }\end{array}$ \\
\hline
\end{tabular}

Table 1. RP techniques for tissue engineering 


\section{Applications of biofabrication to tissue engineering}

\subsection{Biofabrication and architectural design of scaffolds}

The microstructure of scaffolds is increasingly believed to contribute significantly to the diffusion of nutrients and metabolic wastes, spatial organization of cell growth and the development of specific biological functions in tissues. A scaffold with high porosity is desirable for the easy diffusion of nutrients and metabolic wastes and is also beneficial for cell migration and neo-vascularization. A high surface area to volume ratio favors cell attachment and growth. The effect of scaffold pore size on tissue regeneration is also emphasized by experiments demonstrating that (1) an optimum pore size of $5 \mu \mathrm{m}$ is good for neo-vascularization; (2) 5 - $15 \mu \mathrm{m}$ pores are beneficial for fiberblast ingrowth; (3) $20-125 \mu \mathrm{m}$ pores can affect the regeneration of adult mammalian skin; and (4) fibrovascular tissues require pores sizes greater than $500 \mu \mathrm{m}$ [38, 50]. Advanced biofabrication techniques are able to design and precisely control the architecture of scaffolds. They can build scaffolds with reproducible morphology and microstructure that varies across the scaffold matrix to resemble natural tissues with complex hierarchical structures.

Conventional lyophilization can only form porous structures with random orientation. An improved technique for fabricating scaffolds with a linearly oriented architecture is called "freeze casting". Freeze casting facilitates directional solidification of solutions or slurries [51]. During freeze casting, the polymer solution is pipetted into a cylindrical mold fitted with a copper bottom plate and secured onto the temperature-controlled copper cold finger of the freeze casting system. The cold finger temperature is lowered at a constant cooling rate to a final temperature, resulting in the directional solidification of the material dispersion. When the ice is sublimated by freeze drying, the porous microstructure of the resulting scaffold is a negative template of the ice crystals. Freeze casting has been used to produce a wide range of porous, oriented scaffolds from organic and inorganic materials [51, 52]. This technique is also suitable for the fabrication of nerve conduit scaffolds with a featured porous structure that may guide axon growth.

Different scaffold fabrication techniques can be combined to capitalize on their respective positive features for varying applications. The combination of rapid prototyping with lyophilization, in which the polymer solution is dispensed on substrates with a controllable temperature and the strands formed are frozen and lyophilized to remove the solvent, is called "rapid freeze prototyping" technique [53]. This technique has the advantage of fabricating scaffolds with both sub-millimeter and micrometer sized pores [54] (Figure 4). The optimized porous scaffolds can accommodate tissue ingrowth at different scales, from cells to tissues. Scaffolds can also be cold processed so that the polymer can be bio-functionalized without compromising their function during manufacturing. 


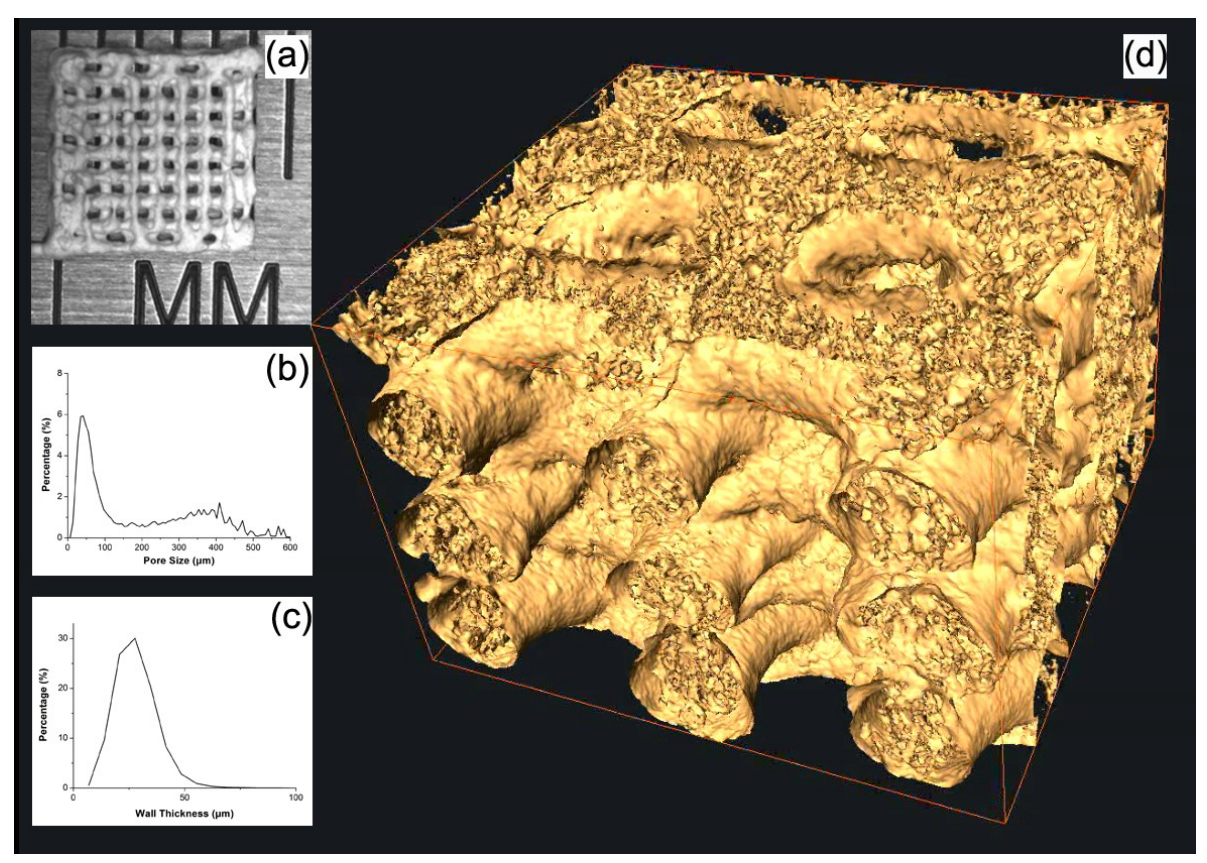

Figure 4. Scaffold fabricated by rapid freeze prototyping: (a) camera image of the scaffold, (b) pore size distribution of the scaffold, (c) wall thickness distribution of the scaffold, and (d) 3D reconstructed model of the scaffold using microtomography. (Modified from [54])

\subsection{Biofabrication and scaffolds with living cells}

Biofabrication of living structures with desired functionality has become a hot topic in tissue engineering in past few years. Conventional cell-seeding methods are inadequate for the development of in vitro tissue-test systems because they involve random placement of cells and, therefore, lack the precision necessary for spatial control. Conventional cell-seeding methods are also a type of 2D cell culture. In contrast, cell cultures in 3D structures allow for a more natural cell attachment and focal adhesion in all directions. The most physiologically relevant cell morphology that can be attained on and in three-dimensional scaffolds will provide the best structural cues to regulate cell function $[55,56]$. Different methods of fabricating 3D scaffolds with living cells have been developed. One of the methods is to spray living cells into the scaffolds throughout the electrospinning process to produce nanofibrous $3 \mathrm{D}$ tissue scaffolds. In this method, cells are periodically sprayed from a pump-action spray bottle onto the developing scaffold during the electrospinning process [56]. The cells can be layered throughout the thickness of the scaffolds, but not incorporated into individual polymer nanofibers.

Living cells also can be directly electrospun, as fine composite threads encapsulating living cells, using a coaxial needle configuration and a biocompatible polymer $[57,58]$. The polymer nanofibers accommodate the survival and proliferation of the cells. Advanced rapid 
prototyping techniques, such as bioprinting, are more capable of incorporating living cells into scaffolds than other techniques. Introducing cells at almost any arbitrary density and precisely into the desired location of a scaffold is possible by means of rapid prototyping. Hydrogel scaffolds, as delivery vehicles for cells, are suitable for bioprinting processes that seed living cells while constructing scaffolds with specific geometries [36]. A pneumatic dispenser system is used to bioprint the cell-associated scaffolds using polymer solution, such as alginate aqueous solutions. The fabrication parameters including pressure and nozzle velocity can be altered, thus affecting the viability of the cells [59]. Complete biological "scaffold free" tissue substitutes can also be engineered with specific compositions and shapes, by exploiting cell-cell adhesion and the ability of cultured cells to grow their own ECM; such approaches have the advantage of reducing and mediating inflammatory responses to biomaterials [60]. For this concept, extrusion-based bioprinting is an automated deposition method that can generate a fully biological construct which is structurally and functionally close to native tissues. Spherical or cylindrical multicellular units (the bio-ink) are delivered according to a computer-generated template with the hydrogel (the bio-paper) serving as the support material. The cells neither invade nor rearrange within the hydrogel, which keeps its integrity during post-printing fusion and can be easily removed to free the fused multicellular construct (Figure 5). The authentic tissues can be assembled through cell adhesion, cell sorting, and tissue fusion processes [37].

(a)

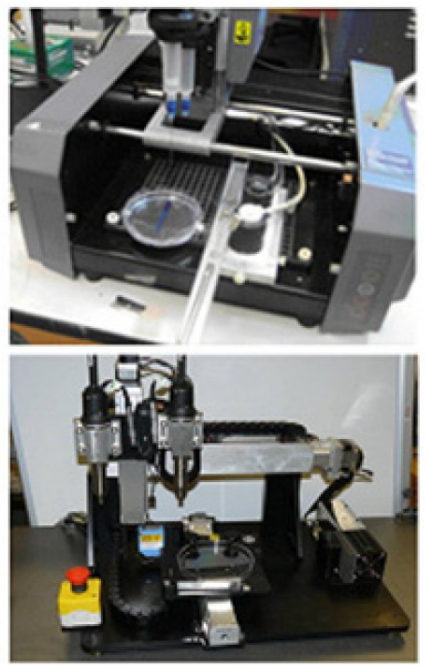

(b)
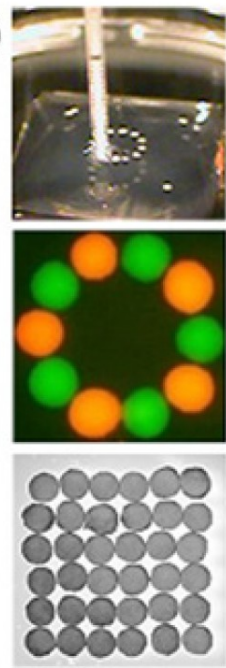

(c)
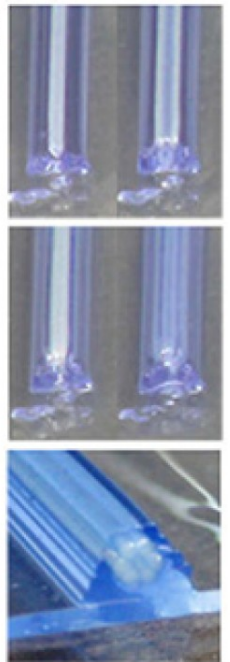

Figure 5. Scaffold-free bioprinting technology: (a) the bio-printer: 3D printing is achieved by means of a three-axis positioning system (stage in $y$ and printing heads along $x$ and $z$ (top: Neatco, Carlisle, Canada; bottom: Organovo-Invetech, San Diego)); (b) spheroids with living cells are delivered one by one into the hydrogel bio-paper according to a computer script; (c) layer-by-layer deposition of cylindrical units of bio-paper (shown in blue) and multicellular cylindrical building blocks. The outcome of printing (spheroids in panel (b), multicellular cylinders in panel (c)) is a set of discrete units, which post-printing fuse to form a continuous structure. (Modified from [60]) 


\section{Summary}

Engineered scaffolds are playing an increasingly important role in tissue engineering. Scaffolds should not only have porous structures and provide mechanical support to new tissue regrowth but also have a complex mimetic hierarchical structure and biological features. Conventional scaffold fabrication techniques fail to meet these requirements for tissue regeneration. Biofabrication technologies have demonstrated potentials in this regard and can be used to create regenerative tissues or organs through the combination of state of the art fabrication techniques, materials science, and cell biology.

\section{Author details}

Ning Zhu and Xiongbiao Chen

Division of Biomedical Engineering, University of Saskatchewan, Saskatoon, SK, Canada

\section{References}

[1] Langer R, Vacanti JP. Tissue Engineering. Science 1993 May;260(5110):920-926.

[2] Liu C, Xia Z, Czernuszka JT. Design and development of three-dimensional scaffolds for tissue engineering. Chemical Engineering Research \& Design 2007 Jul;85(A7): 1051-1064.

[3] Prabhakaran MP, Ghasemi-Mobarakeh L, Ramakrishna S. Electrospun composite nanofibers for tissue regeneration. Journal of Nanoscience and Nanotechnology 2011 Apr;11(4):3039-3057.

[4] Peltola SM, Melchels FPW, Grijpma DW, Kellomaki M. A review of rapid prototyping techniques for tissue engineering purposes. Annals of Medicine 2008;40(4): 268-280.

[5] Mironov V, Trusk T, Kasyanov V, Little S, Swaja R, Markwald R. Biofabrication: a 21st century manufacturing paradigm. Biofabrication 2009 Jun;1(2):022001.

[6] Hsu SH, Su CH, Chiu IM. A novel approach to align adult neural stem cells on micropatterned conduits for peripheral nerve regeneration: A feasibility study. Artificial Organs 2009 Jan;33(1):26-35.

[7] Yang Y, De Laporte L, Rives CB, Jang JH, Lin WC, Shull KR, et al. Neurotrophin releasing single and multiple lumen nerve conduits. Journal of Controlled Release 2005 Jun;104(3):433-446. 
[8] Khorasani MT, Mirmohammadi SA, Irani S. Polyhydroxybutyrate (PHB) scaffolds as a model for nerve tissue engineering application: Fabrication and in vitro assay. International Journal of Polymeric Materials 2011;60(8):562-575.

[9] Pego AP, Poot AA, Grijpma DW, Feijen J. Biodegradable elastomeric scaffolds for soft tissue engineering. Journal of Controlled Release 2003 Feb;87(1-3):69-79.

[10] Huang YC, Huang YY, Huang CC, Liu HC. Manufacture of porous polymer nerve conduits through a lyophilizing and wire-heating process. Journal of Biomedical Materials Research Part B-Applied Biomaterials 2005 Jul;74B(1):659-664.

[11] Mikos AG, Thorsen AJ, Czerwonka LA, Bao Y, Langer R, Winslow DN, et al. Preparation and characterization of poly(L-lactic acid) foams. Polymer 1994 1994;35(5): 1068-1077.

[12] Mikos AG, Sarakinos G, Vacanti JP, Langer R, Cima LG, inventors. Biocompatible polymer membranes and methods of preparation of three dimensional membrane structures. United States Patent No. 5514378, 1996.

[13] Di Maio E, Mensitieri G, Iannace S, Nicolais L, Li W, Flumerfelt RW. Structure optimization of polycaprolactone foams by using mixtures of $\mathrm{CO}_{2}$ and $\mathrm{N}_{2}$ as blowing agents. Polymer Engineering and Science 2005 Mar;45(3):432-441.

[14] Haugen H, Ried V, Brunner M, Will J, Wintermantel E. Water as foaming agent for open cell polyurethane structures. Journal of Materials Science-Materials in Medicine 2004 Apr;15(4):343-346.

[15] Parks KL, Beckman EJ. Generation of microcellular polyurethane foams via polymerization in carbon dioxide .2. Foam formation and characterization. Polymer Engineering and Science 1996 Oct;36(19):2417-2431.

[16] Quirk RA, France RM, Shakesheff KM, Howdle SM. Supercritical fluid technologies and tissue engineering scaffolds. Current Opinion in Solid State \& Materials Science 2004 Jun-Aug;8(3-4):313-321.

[17] Lee KWD, Chan PK, Feng XS. Morphology development and characterization of the phase-separated structure resulting from the thermal-induced phase separation phenomenon in polymer solutions under a temperature gradient. Chemical Engineering Science 2004 Apr;59(7):1491-1504.

[18] Ma PX, Zhang RY. Synthetic nano-scale fibrous extracellular matrix. Journal of Biomedical Materials Research 1999 Jul;46(1):60-72.

[19] Thomson RC, Wake MC, Yaszemski MJ, Mikos AG. Biodegradable polymer scaffolds to regenerate organs. Advances in Polymer Science 1995: 245-274.

[20] Pikal MJ, Shah S, Roy ML, Putman R. The secondary drying stage of freeze-dring kinetics as a function of temperature and chamber pressure. International Journal of Pharmaceutics 1990 May;60(3):203-217. 
[21] Liapis AI, Bruttini R. A theory for the primary and secondary drying stages of the freeze-drying of pharmaceutical crystalline and amorphous solutes - comparison between experimental - data and theory. Separations Technology 1994 Jul;4(3):144-155.

[22] Bischof JC, He XM. Thermal stability of proteins. In: Lee RC, Despa F, Hamann KJ, editors. Cell Injury: Mechanisms, Responses, and Repair, 2005. p. 12-33.

[23] Puppi D, Chiellini F, Piras AM, Chiellini E. Polymeric materials for bone and cartilage repair. Progress in Polymer Science 2010 Apr;35(4):403-440.

[24] Subbiah T, Bhat GS, Tock RW, Pararneswaran S, Ramkumar SS. Electrospinning of nanofibers. Journal of Applied Polymer Science 2005 Apr 15;96(2):557-569.

[25] Stevens MM, George JH. Exploring and engineering the cell surface interface. Science 2005 Nov 18;310(5751):1135-1138.

[26] Huang ZM, Zhang YZ, Kotaki M, Ramakrishna S. A review on polymer nanofibers by electrospinning and their applications in nanocomposites. Composites Science and Technology 2003 Nov;63(15):2223-2253.

[27] Pham QP, Sharma U, Mikos AG. Electrospinning of polymeric nanofibers for tissue engineering applications: A review. Tissue Engineering 2006 May;12(5):1197-1211.

[28] Jain KK. Role of nanotechnology in developing new therapies for diseases of the nervous system. Nanomedicine 2006 Jun;1(1):9-12.

[29] Bhardwaj N, Kundu SC. Electrospinning: A fascinating fiber fabrication technique. Biotechnology Advances 2010 May-Jun;28(3):325-347.

[30] Yeong WY, Chua CK, Leong KF, Chandrasekaran M. Rapid prototyping in tissue engineering: challenges and potential. Trends in Biotechnology 2004 Dec;22(12):643-652.

[31] Karalekas DE. Study of the mechanical properties of nonwoven fibre mat reinforced photopolymers used in rapid prototyping. Materials \& Design 2003 Dec;24(8):665-670.

[32] Wiria FE, Leong KF, Chua CK, Liu Y. Poly-epsilon-caprolactone/hydroxyapatite for tissue engineering scaffold fabrication via selective laser sintering. Acta Biomaterialia 2007 Jan;3(1):1-12.

[33] Hutmacher DW, Schantz T, Zein I, Ng KW, Teoh SH, Tan KC. Mechanical properties and cell cultural response of polycaprolactone scaffolds designed and fabricated via fused deposition modeling. Journal of Biomedical Materials Research 2001 May;55(2):203-216.

[34] Lam CXF, Mo XM, Teoh SH, Hutmacher DW. Scaffold development using 3D printing with a starch-based polymer. Materials Science \& Engineering C-Biomimetic and Supramolecular Systems 2002 May 31;20(1-2):49-56.

[35] Landers R, Mulhaupt R. Desktop manufacturing of complex objects, prototypes and biomedical scaffolds by means of computer-assisted design combined with computer-guided 3D plotting of polymers and reactive oligomers. Macromolecular Materials and Engineering 2000 Oct;282(9):17-21. 
[36] Khalil S, Sun W. Bioprinting endothelial cells with alginate for 3D tissue constructs. Journal of Biomechanical Engineering-Transactions of the ASME 2009 Nov;131(11).

[37] Mironov V, Kasyanov V, Drake C, Markwald RR. Organ printing: promises and challenges. Regenerative Medicine 2008 Jan;3(1):93-103.

[38] Yu D, Li Q, Mu X, Chang T, Xiong Z. Bone regeneration of critical calvarial defect in goat model by PLGA/TCP/rhBMP-2 scaffolds prepared by low-temperature rapidprototyping technology. International Journal of Oral and Maxillofacial Surgery 2008 Oct;37(10):929-934.

[39] Chang PSH, Parker TH, Patrick CW, Miller MJ. The accuracy of stereolithography in planning craniofacial bone replacement. Journal of Craniofacial Surgery 2003 Mar; 14(2):164-170.

[40] Sodian R, Loebe M, Hein A, Martin DP, Hoerstrup SP, Potapov EV, et al. Application of stereolithography for scaffold fabrication for tissue engineered heart valves. ASAIO Journal 2002 Jan-Feb;48(1):12-16.

[41] Williams JM, Adewunmi A, Schek RM, Flanagan CL, Krebsbach PH, Feinberg SE, et al. Bone tissue engineering using polycaprolactone scaffolds fabricated via selective laser sintering. Biomaterials 2005 Aug;26(23):4817-4827.

[42] Cruz F, Simoes J, Coole T, Bocking C. Direct manufacture of hydroxyapatite based bone implants by Selective Laser Sintering, $2^{\text {nd }}$ International Conference on Advanced Research and Rapid Prototyping (VRAP 2005), September 28 - October 1, 2005, Leiria, Portugal.

[43] Chen C-H, Chen J-P, Lee M-Y. Eeffects of gelatin modification on rapid prototyping PCL scaffolds for cartilage engineering. Journal of Mechanics in Medicine and Biology 2011 Dec;11(5):993-1002.

[44] Rohner D, Hutmacher DW, Cheng TK, Oberholzer M, Hammer B. In vivo efficacy of bone-marrow-coated polycaprolactone scaffolds for the reconstruction of orbital defects in the pig. Journal of Biomedical Materials Research Part B-Applied Biomaterials 2003 Aug 15;66B(2):574-580.

[45] Wiggenhauser PS, Mueller DF, Melchels FPW, Egana JT, Storck K, Mayer H, et al. Engineering of vascularized adipose constructs. Cell and Tissue Research 2012 Mar; 347(3):747-757.

[46] Koo S, Hargreaves BA, Gold GE, Dragoo JL. Fabrication of custom-shaped grafts for cartilage regeneration. The International Journal of Artificial Organs 2010 Oct;33(10): 731-737.

[47] Seitz H, Rieder W, Irsen S, Leukers B, Tille C. Three-dimensional printing of porous ceramic scaffolds for bone tissue engineering. Journal of Biomedical Materials Research Part B-Applied Biomaterials 2005 Aug;74B(2):782-788. 
[48] Yilgor P, Sousa RA, Reis RL, Hasirci N, Hasirci V. 3D plotted PCL scaffolds for stem cell based bone tissue engineering. Macromolecular Symposia 2008 2008;269:92-99.

[49] El-Ayoubi R, Degrandpre C, DiRaddo R, Yousefi AM, Lavigne P. Design and dynamic culture of 3D-scaffolds for cartilage tissue engineering. Journal of Biomaterials Applications 2011 Jan;25(5):429-444.

[50] Whang K, Healy KE, Elenz DR, Nam EK, Tsai DC, Thomas CH, et al. Engineering bone regeneration with bioabsorbable scaffolds with novel microarchitecture. Tissue Engineering 1999 Spr;5(1):35-51.

[51] Wegst UGK, Schecter M, Donius AE, Hunger PM. Biomaterials by freeze casting. Philosophical Transactions of the Royal Society a-Mathematical Physical and Engineering Sciences 2010 Apr 28;368(1917):2099-2121.

[52] Zhang H, Cooper AI. Aligned porous structures by directional freezing. Advanced Materials 2007 Jun 4;19(11):1529-1533.

[53] Pham CB, Leong KF, Lim TC, Chian KS. Rapid freeze prototyping technique in bioplotters for tissue scaffold fabrication. Rapid Prototyping Journal 2008;14(4):246-253.

[54] Zhu N, Li MG, Cooper D, Chen XB. Development of novel hybrid poly(l-lactide)/ chitosan scaffolds using the rapid freeze prototyping technique. Biofabrication 2011;3(3):034105.

[55] Albrecht DR, Underhill GH, Wassermann TB, Sah RL, Bhatia SN. Probing the role of multicellular organization in three-dimensional microenvironments. Nature Methods 2006 May;3(5):369-375.

[56] Seil JT, Webster TJ. Spray deposition of live cells throughout the electrospinning process produces nanofibrous three-dimensional tissue scaffolds. International Journal of Nanomedicine 2011 2011;6:1095-1099.

[57] Townsend-Nicholson A, Jayasinghe SN. Cell electrospinning: a unique biotechnique for encapsulating living organisms for generating active biological microthreads/ scaffolds. Biomacromolecules 2006 Dec 11;7(12):3364-3369.

[58] Hamid Q, Sun W, Asme. Coaxial electrospinning biopolymer with living cells, ASME 2010 First Global Congress on NanoEngineering for Medicine and Biology (NEMB2010), February 7-10, 2010, Houston, Texas, USA; Paper no. NEMB2010-13282, pp. 167-172.

[59] Khalil S, Sun W. Biopolyrner deposition for freefonn fabrication of hydrogel tissue constructs. Materials Science \& Engineering C-Biomimetic and Supramolecular Systems 2007 Apr;27(3):469-478.

[60] Jakab K, Norotte C, Marga F, Murphy K, Vunjak-Novakovic G, Forgacs G. Tissue engineering by self-assembly and bio-printing of living cells. Biofabrication 2010 Jun; 2(2). 